\title{
Antibacterial Activities of Methanolic Extracts of Different Seaweeds from Iskenderun Bay, Turkey
}

\author{
Betul Aydin 1 ,**
}

${ }^{1}$ Department of Biology, Faculty of Science, Gazi University, Ankara, TURKEY

\begin{abstract}
Antibacterial activities of the methanolic extracts of Stypopodium schimperi (Kützing) Verlaque and Boudouresque, Halopteris filicina (Grateloup) Kützing, Dictyota dichotoma (Hudson) J.V.Lamouroux, Gracilaria bursa-pastoris (S.G.Gmelin) P.C.Silva, Ulva intestinalis Linnaeus species from the Iskenderun Bay, Turkey against Escherichia coli, Bacillus cereus, Staphylococcus aureus, Pseudomonas aeruginosa, Klebsiella pneumoniae, Salmonella typhimurium and Proteus vulgaris were evaluated by using the microdilution method. Results of the study showed that all of the extracts had an antimicrobial effect on the tested bacteria. A minimum inhibitor concentration and minimum bactericidal concentrations of the extracts ranged from $>125$ to $<0.39 \mathrm{mg} \mathrm{mL}^{-1}$. Furthermore, this is the first report on antibacterial effects of the methanolic extracts of $S$. schimperi (Kützing) Verlaque and Boudouresque and G. bursa-pastoris (S.G.Gmelin) P.C.Silva species. The present findings revealed that all studied seaweed species could act as a natural source of bioactive compounds for the treatment of infectious diseases.
\end{abstract}

\section{ARTICLE HISTORY}

Received: Mar. 10, 2021

Revised: Apr. 26, 2021

Accepted: May 05, 2021

\section{KEYWORDS}

Antimicrobial activity, Brown macroalgae,

Red macroalgae,

Green macroalgae.

\section{INTRODUCTION}

For centuries, human beings have suffered from infectious diseases caused by various pathogenic microorganisms. The discovery of antibiotics used to control infectious diseases has been a beacon of hope to reduce the deaths caused by these diseases. Today, however, people are in danger of losing this powerful weapon due to resistant strains caused by the improper use of antibiotics. For this reason, researchers have been examining many natural resources for the discovery of new antibiotics (Mohr, 2016; Zaman et al., 2017). One of these natural resources is seaweed, which has many important medical properties due to the valuable components it contains (Shelar et al., 2012). Seaweeds also known as macroalgae are photosynthetic eukaryotic organisms that are essential components of the living resources of the sea. Seaweeds consist of three main classes; namely, Rhodophtya (red algae), Chlorophyta (green algae) and Phaeophyta (brown algae) (Wang et al., 2017). In some studies to date, it has been observed 
that many species of algae can synthesize antimicrobial metabolites such as bromophenols, indolocarbazoles, cycloeudesmol, laurinterol, and elatol to kill or inactivate the pathogen microorganisms (Parsaeimehr and Lutzu, 2016).

There is a very rich variety of seaweed in Turkey, which has coasts in the Mediterranean, Black Sea and Aegean Sea, as well as an inland sea called the Marmara Sea (Aysel and Erdugan, 1996; Ribera et al., 1992; Taskin, 2014). There are some studies on the biochemical composition (total protein, carbohydrate, phenolic, chlorophyll-a and carotene contents) of some brown, green and red seaweeds from Iskenderun Bay in the Mediterranean Sea in the south of Turkey (Ozgun et al., 2015; Turan et al., 2015). On the other hand, there are no studies in the literature showing the antimicrobial effects of the methanolic extracts of Stypopodium schimperi (Kützing) Verlaque and Boudouresque and Gracilaria bursa-pastoris (S.G.Gmelin) P.C.Silva species.

The aim of this study is to determine the antimicrobial effect of methanol extract of seaweeds; namely, Stypopodium schimperi (Kützing) Verlaque and Boudouresque (Phaeophyta), Halopteris filicina (Grateloup) Kützing (Phaeophyta), Dictyota dichotoma (Hudson) J.V.Lamouroux (Phaeophyta), Gracilaria bursa-pastoris (S.G.Gmelin) P.C.Silva (Rhodophyta), and Ulva intestinalis Linnaeus (Chlorophyta) collected from the Iskenderun Bay, on various bacteria.

\section{MATERIAL and METHODS}

\subsection{Sample Collection}

Antimicrobial activity analysis was performed on Stypopodium schimperi, Halopteris filicina, Dictyota dichotoma, Gracilaria bursa-pastoris, and Ulva intestinalis species (Table 1). Sampling studies were carried out in June 2018 at 0-20 m depth from free dives on the Iskenderun Gulf coast, Hatay, Turkey. The seaweeds were collected underwater in gathered mesh bags. The collected seaweeds were washed with water to remove the epiphytes, rocks, sand and mud that could be present. In the laboratory, the washed materials were dried in a shaded environment without sun exposure for further study. Some of the collected seaweeds were stored in jars with a 4-6\% neutralized formaldehyde solution prepared with seawater for identification. The identification of the seaweeds was carried out using the Olympus brand Ckx41sf model stereo inverted light microscope.

Table 1. Macroalgae species used in antimicrobial activity test.

\begin{tabular}{cc}
\hline Seaweed species & Class \\
\hline Stypopodium schimperi (Kützing) Verlaque and Boudouresque 1991 & \\
Halopteris filicina (Grateloup) Kützing 1843 & Brown algae \\
Dictyota dichotoma (Hudson) J.V.Lamouroux 1809 & \\
Gracilaria bursa-pastoris (S.G.Gmelin) P.C.Silva 1952 & Red algae \\
Ulva intestinalis Linnaeus 1753 & Green algae \\
\hline
\end{tabular}

\subsection{Preparation of the Extracts}

The dried algal samples were extracted by maceration in $1.4(\mathrm{w} / \mathrm{v})$ biomass/solvent ratio with methanol for 2 weeks at room temperature in a dark environment. The obtained methanolic extract was filtered through filter paper. After the filtration, the solvent was evaporated at 50 ${ }^{\circ} \mathrm{C}$ under reduced pressure in a rotary evaporator (Heidolph, Germany), and deposited at $+4{ }^{\circ} \mathrm{C}$ before further usage. For antimicrobial analysis, the extracts were dissolved in DMSO at a concentration of $250 \mathrm{mg} \mathrm{mL}^{-1}$ and sterilized by a $0.45 \mathrm{~mm}$ pore sized syringe filter. 


\subsection{Microorganisms and Growth Conditions}

Seven bacterial strains have been used to detect the antimicrobial activities of the extracts. Bacterial strains were as follows: Gram positive bacteria, Bacillus cereus NRRL B-371, Staphylococcus aureus ATCC 25923, gram negative bacteria, Escherichia coli ATCC 35218, Pseudomonas aeruginosa ATCC 27853, Klebsiella pneumoniae ATCC 13883, Salmonella typhimurium ATCC 14028, Proteus vulgaris RSKK 96029. All the bacterial cultures were incubated in Tryptic soy agar at $37^{\circ} \mathrm{C}$ for $24 \mathrm{~h}$.

\subsection{Broth Microdilution Assay}

The minimum inhibitory concentrations (MIC) of the extracts were evaluated by the broth microdilution assay in 96-well microtiter plates according to CLSI reference methods for bacteria M07 (CLSI, 2018). Serial dilutions of the samples were made in Mueller Hinton broth at a concentration range of $125-0.39 \mathrm{mg} \mathrm{mL}^{-1}$ on 96 -well microtiter plates. The antibiotics ampicillin and chloramphenicol (Sigma) were used as positive control. Microorganism inoculums were prepared from a 24-hour culture, suspensions in $0.9 \%$ of $\mathrm{NaCl}$ were adjusted to $0.5 \mathrm{McFarland}$ standard turbidity $\left(1.5 \times 10^{8} \mathrm{cfu} \mathrm{mL}^{-1}\right)$, and this microbial suspension was diluted $10^{-1}$ in $0.9 \%$ of $\mathrm{NaCl}$ solution. Five microliters of the diluted microbial suspension had been added to all wells. The plates were then incubated for $24 \mathrm{~h}$ at $37^{\circ} \mathrm{C}$. After the incubation, the minimum inhibitory concentration (MIC) values of the extracts were determined by absence of visual turbidity. The minimum bactericidal concentration $(\mathrm{MBC})$ values were determined by subculturing ten microliters from non-turbid wells and spot inoculated onto an appropriate growth medium. After the incubation, the growth was recorded and MBCs were defined as the lowest concentration resulting in the death of $99.9 \%$ of the inoculum compared to the initial viable counts. The assay was repeated at least three times and the mean values of MIC and MBC were selected.

\section{RESULTS and DISCUSSION}

Antimicrobial activity of the seaweed extracts was evaluated by using the microdilution method. MIC and MBC values of five methanolic seaweed extracts against tested bacteria are given in Table 2 and Table 3, respectively. According to the obtained results MIC and MBC values ranged from $<0.39$ to $>125 \mathrm{mg} \mathrm{mL}^{-1}$. All extracts were found to have a strong bactericidal and bacteriostatic effect on the studied bacteria.

Table 2. Minimum inhibitory concentration (MIC) values of the extracts $\left(\mathrm{mg} \mathrm{mL}^{-1}\right)$.

\begin{tabular}{|c|c|c|c|c|c|c|c|}
\hline & \multicolumn{2}{|c|}{$\begin{array}{l}\text { Gram } \\
\text { positive }\end{array}$} & \multicolumn{5}{|c|}{$\begin{array}{c}\text { Gram } \\
\text { negative }\end{array}$} \\
\hline & 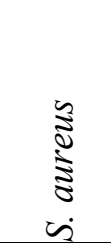 & 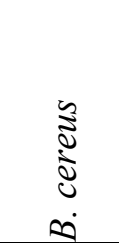 & $\begin{array}{l}\ddot{8} \\
0 \\
10\end{array}$ & 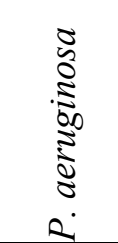 & 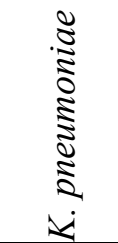 & 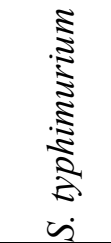 & 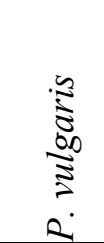 \\
\hline Stypopodium schimperi & 3.13 & 3.13 & 12.5 & 3.13 & 1.56 & 6.25 & 12.5 \\
\hline Halopteris filicina & 15.63 & 15.63 & 125 & 31.25 & 31.25 & 31.25 & 31.25 \\
\hline Dictyota dichotoma & 50 & 1.56 & 50 & $<0.39$ & 12.5 & 50 & 12.5 \\
\hline Gracilaria bursa-pastoris & 50 & 6.25 & 50 & 1.56 & 12.5 & 50 & 25 \\
\hline Ulva intestinalis & 12.5 & 1.56 & 25 & 12.5 & 12.5 & 50 & 25 \\
\hline Ampicillin & 62.5 & 31.25 & $>125$ & $>125$ & 125 & 62.5 & $>125$ \\
\hline Chloramphenicol & 125 & 125 & $>125$ & $>125$ & 15.63 & 125 & 125 \\
\hline
\end{tabular}


Table 3. Minimum bactericidal concentration $(\mathrm{MBC})$ values of the extracts $\left(\mathrm{mg} \mathrm{mL}^{-1}\right)$.

\begin{tabular}{cc}
\hline Gram & Gram \\
positive & negative \\
\hline
\end{tabular}

\begin{tabular}{|c|c|c|c|c|c|c|c|}
\hline & 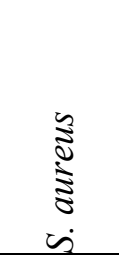 & 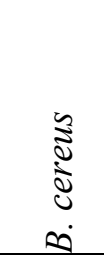 & $\begin{array}{l}\dot{0} \\
0\end{array}$ & 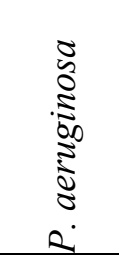 & 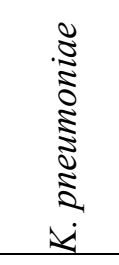 & 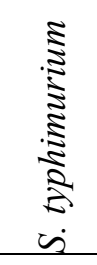 & 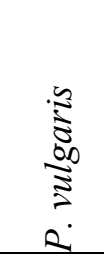 \\
\hline Stypopodium schimperi & 6.25 & 3.13 & 12.5 & 3.13 & 6.25 & 6.25 & 12.5 \\
\hline Halopteris filicina & 62.5 & $>125$ & $>125$ & 62.5 & $>125$ & 125 & 62.5 \\
\hline Dictyota dichotoma & 50 & 1.56 & 50 & $<0.39$ & 50 & 50 & 12.5 \\
\hline Gracilaria bursa-pastoris & 50 & 25 & 50 & 1.56 & 50 & 50 & 25 \\
\hline Ulva intestinalis & 25 & 1.56 & 50 & 12.5 & 50 & 50 & 25 \\
\hline Ampicillin & 62.5 & $>125$ & $>125$ & $>125$ & 125 & 62.5 & $>125$ \\
\hline Chloramphenicol & $>125$ & 125 & $>125$ & $>125$ & 15.63 & 125 & $>125$ \\
\hline
\end{tabular}

Among the bacteria tested, extracts were found to demonstrate the highest antimicrobial effect on $B$. cereus. The lowest MIC and MBC values were recorded for the $D$. dichotoma extract against $P$. aeruginosa $\left(<0.39 \mathrm{mg} \mathrm{mL}^{-1}\right)$. Methanolic extract of $S$. schimperi showed a higher antimicrobial effect against the tested bacteria than the other algal species.

Ballesteros et al. screened the antibacterial, antifungal, antiviral, cytotoxic, and antimytotic properties of seventy-one different macroalgae species collected from the Central Mediterranean (Ballesteros et al., 1992). They said that antifungal activity (against Candida albicans and Aspergillus niger) was more common than antibacterial activity (against E. coli and B. subtilis) among these species and H. filicina did not have antibacterial effects. Val et al. studied the antibacterial and antifungal activities of the methanol extracts from 44 species harvested from Gran Canaria (Canary Islands, Spain) against B. subtilis MB964, Enterococcus faecium MB5571, S. aureus MB5393, P. aeruginosa MB979, Serratia marcescens MB252, Mycobacterium smegmatis MB2233, Candida albicans MY1055, Saccharomyces cerevisiae W303, Aspergillus fumigatus MF5668 (Val et al., 2001). They found that $H$. filicina extract did not have any antimicrobial effects against these microorganisms. However, Alghazeer et al. evaluated the antibacterial activity of crude methanolic and water extracts of 19 seaweed species collected from the western coast of Libya against $S$. aureus, B. subtilis, Bacillus spp., Staphylococcus epidermidis, E. coli, Salmonella typhi, Klebsiella spp., and P. aeruginosa (Alghazeer et al., 2013). They found that methanol extract of H. filicina was less effective than the positive control antibiotic, ciprofloxacin. Taskin et al. studied the antibacterial activity of methanol extracts of six marine algae from the North Aegean Sea (Turkey) against $S$. aureus, Micrococcus luteus, Enterococcus faecalis, E. coli, Enterobacter aerogenes and E. coli O157,H7 (Taskin et al., 2007). They determined that $H$. filicina methanol extract had a moderate antibacterial effect only on $S$. aureus among the bacteria studied. In our study, it was observed that $H$. filicina extract was less effective on the tested bacteria than the other extracts. This difference between the results could have been due to the difference in preparation methods such as concentration of extract, type of the solvent and extraction technique or some ecological factors such as the location and season of sampling.

$D$. dichotoma extract showed an antibacterial effect in variable values against studied bacteria. This was in consistence with the finding of Ibraheem et al. and Demirel et al. (2009) 
who found that the extracts of $D$. dichotoma obtained from Hurghada on the Red-Sea coast of Egypt and Aegean Sea had antimicrobial properties on both gram positive and gram negative bacteria (Ibraheem et al., 2017; Demirel et al., 2009).

Like other species, $U$. intestinalis extract has been found to have a fairly high antimicrobial effect, similar to previous studies (Abdel-Khaliq et al., 2014; Berber et al., 2015; Sahnouni et al., 2016; Srikong et al., 2017; Srikong et al., 2015). Berber et al. tested the antimicrobial activities of the methanolic extracts of Cystoseira crinita Duby and $U$. intestinalis from the coastal region of Sinop, Turkey against 18 bacteria and 3 yeasts. According to their results, $U$. intestinalis extract had a moderate antibacterial effect on 10 bacteria out of 18 species (Berber et al., 2015). Srikong et al. evaluated the antibacterial activities of methanol, ethanol, dichloromethane, and hexane extracts of $U$. intestinalis harvested from Thailand on Bacillus cereus TISTR 687, Enterococcus faecalis ATCC 29212, Listeria monocytogenes DMST 4553, S. aureus ATCC 29213 and methicillin-resistant S. aureus $001 \mathrm{R}$ (MRSA $001 \mathrm{R})$, E. coli ATCC 25922, K. pneumonia PSU 1, Proteus mirabilis PSU 1, P. aeruginosa ATCC 27853, Salmonella typhi PSU 1, Vibrio alginolyticus PSU VA 1, V. harveyi PSU 4109 and V. parahaemolyticus PSU 5124. They found that only the hexane extract had a significant antibacterial activity against Gram-positive bacteria but not against Gram-negative bacteria (Srikong et al., 2017). Moreover, Sahnouni et al. studied Ulva rigida C. Agardh and $U$. intestinalis methanolic extracts for antimicrobial activities on E. coli, Salmonella sp., Shigella dysentriae, P. aeruginosa, multidrug resistant Proteus mirabilis, sensitive Streptococcus pyogenes, methicillin-resistant S.aureus (MRSA), Staphylococcus epidermidis, K. pneumoniae, vancomycin resistant Enterococcus faecalis, C. albicans, A. niger and Cryptococcus neoformans. They showed that E. coli, S. pyogenes and S. epidermidis bacteria were more susceptible to $U$. intestinalis extract than the other bacteria studied (Sahnouni et al., 2016).

There are no studies on the antimicrobial effects of the S. schimperi and G. bursa-pastoris species. Both of the species have been found to inhibit the growth of all bacteria studied. Therefore, this initial data is very important as it reveals the antimicrobial potential of these species.

\section{CONCLUSION}

Findings obtained from this study suggest that methanolic extracts of S. schimperi, H. filicina, D. dichotoma, G. bursa-pastoris and U. intestinalis species from Iskenderun Bay are potential natural source of antibacterial agents. In particular, the lack of any study showing the antimicrobial effectiveness of the $S$. schimperi and G. bursa-pastoris species has made this study the first research to reveal the antimicrobial properties of these species. Further studies will pave the way for the use of active substances contained in these algae in the field of pharmacy and medicine. Therefore, detailed research should be carried out for the detection of their active components.

\section{Declaration of Conflicting Interests and Ethics}

The author declare no conflict of interest. This research study complies with research and publishing ethics. The scientific and legal responsibility for manuscripts published in IJSM belongs to the author.

\section{Orcid}

All authors must write ORCID

Betül Aydın (I) https//orcid.org/0000-0002-9092-1350 


\section{REFERENCES}

Abdel-Khaliq, A., Hassan, H., Rateb, M.E., Hammouda, O. (2014). Antimicrobial Activity of Three Ulva Species Collected from Some Egyptian Mediterranean Seashores. IJERGS, 2(5), 648-669.

Alghazeer, R., Whida, F., Abduelrhman, E., Gammoudi, F., Azwai, S. (2013). Screening of Antibacterial Activity in Marine Green, Red and Brown Macroalgae from The Western Coast of Libya. Nat.Sci., 05(01), 7-14. https//doi.org/10.4236/ns.2013.51002

Aysel, V., Erdugan, H. (1996). Check-list of Black Sea Seaweeds, Turkey (1823-1994). Oceanog. Lit. Rev., 5(43), 500.

Ballesteros, E., Martín, D., Uriz, M.J. (1992). Biological Activity of Extracts from Some Mediterranean Macrophytes. Bot. Mar., 35(6), 481-485. http//dx.doi.org/10.1515/botm.199 2.35.6.481

Berber, I., Avşar, C., Koyuncu, H. (2015). Antimicrobial and Antioxidant Activities of Cystoseira crinita Duby and Ulva intestinalis Linnaeus From the Coastal Region of Sinop, Turkey. J. Coastal Life Med., 3(6), 441-445. https//doi.org/10.12980/JCLM.3.2015JCLM$\underline{2015-0013}$

CLSI. (2018). Methods for Dilution Antimicrobial Susceptibility Tests for Bacteria That Grow Aerobically-11th edition. CLSI standart M07. In. Wayne, PA, Clinical and Laboratory Standards Institute.

Demirel, Z., Yilmaz-Koz, F., Karabay-Yavasoglu, U., Ozdemir, G., Sukatar, A. (2009). Antimicrobial and Antioxidant Activity of Brown Algae from the Aegean Sea. J. Serb. Chem. Soc., 74(6), 619-628. https//doi.org/10.2298/JSC0906619D

Ibraheem, I., Abdel-Raouf, N., Mohamed, H., Fassihy, R., Hamed, S. (2017). Impact of The Microbial Suppression by Using the Brown Alga Dictyota dichotoma Extract. Egypt. J. Bot., 57, 205-214. https//doi.org/10.21608/ejbo.2017.912.1072

Mohr, K.I. (2016). History of Antibiotics Research. Curr. Top. Microbiol. Immunol., 398, $237-$ 272.

Ozgun, S., Turan, F., Çinar, M.E., Bakir, K., Öztürk, B., Katağan, T., Bakır, B. (2015). Biochemical Composition of Some Brown Algae from Iskenderun Bay, the Northeastern Mediterranean Coast of Turkey. J. Black Sea/Medit. Environ., 21(2), 125-134.

Parsaeimehr, A., Lutzu, G. (2016). Algae as a Novel Source of Antimicrobial Compounds, Current and Future Perspectives. (Antibiotic resistance, 1st edn. Elsevier, London) 377-396.

Ribera, M., Garreta, A.G., Gallard, T., Cormaci, M., Furnari, G., Giaccone, G. (1992). Checklist of Mediterranean Seaweeds. I. Fucophyceae (Warming, 1884). Bot. Mar., 35(2), 109130.

Sahnouni, F., Benattouche, Z., Matallah-Boutiba, A., Benchohra, M., Moumen Chentouf, W., Bouhadi, D., Boutiba, Z. (2016). Antimicrobial Activity of Two Marine Algae Ulva rigida and Ulva intestinalis Collected from Arzew Gulf (Western Algeria). J. Appl. Environ. Biol. Sci., 6(1), 242-248.

Shelar, P.S., Reddy, S.V.K., Shelar, G.S., Kavitha, M., Kumar, G.P., Reddy, G.V.S. (2012). Medicinal Value of Seaweeds and Its Applications - A Review. CJPTRes., 5(2), 1-22.

Srikong, W., Bovornreungroj, N., Mittraparparthorn, P., Bovornreungroj, P. (2017). Antibacterial and Antioxidant Activities of Differential Solvent Extractions from the Green Seaweed Ulva intestinalis. Science Asia, 43, 88-95. https//doi.org/10.2306/scienceasia15131874.2017 .43 .088

Srikong, W., Mittraparp-Arthorn, P., Rattanaporn, O., Bovornreungroj, N., Bovornreungroj, P. (2015). Antimicrobial Activity of Seaweed Extracts from Pattani, Southeast Coast of Thailand. FABJ., 3(1), 39-49. https//doi.org/10.14456/fabj.2015.5

Taskin, E. (2014). Comparison of the Brown Algal Diversity Between Four Sea Casts of Turkey. Journal of Academic Documents for Fisheries and Aquaculture, 1(3), 145-153. 
Taskin, E., Ozturk, M., Taskin, E., Kurt, O. (2007). Antibacterial Activities of Some Marine Algae from the Aegean Sea (Turkey). Afr. J. Biotechnol., 6(24), 2746-2751. https//doi.org/10.5897/AJB2007.000-2439

Turan, F., Ozgun, S., Sayın, S., Ozyılmaz, G. (2015). Biochemical Composition of Some Red and Green Seaweeds from Iskenderun Bay, the Northeastern Mediterranean Coast of Turkey. J. Black Sea/Medit. Environ., 21, 239-249.

Val, A., Platas, G., Basilio, A., Cabello, A., Gorrochategui, J., Suay, I., Vicente, F., Portillo, E., Río, M., Reina, G. (2001). Screening of Antimicrobial Activities in Red, Green and Brown Macroalgae from Gran Canaria (Canary Islands, Spain). Int. Microbiol., 4(1), 35-40. https//doi.org/10.1007/s101230100006

Wang, H.M.D., Li, X.C., Lee, D.J., Chang, J.S. (2017). Potential Biomedical Applications of Marine Algae. Bioresour. Technol., 244, 1407-1415. https//doi.org/10.1016/j.biortech.2017 .05 .198

Zaman, S.B., Hussain, M.A., Nye, R., Mehta, V., Mamun, K.T., Hossain, N. (2017). A Review on Antibiotic Resistance, Alarm Bells are Ringing. Cureus, 9(6), e1403. https//doi.org/10.7759/cureus.1403 